\title{
Simulating the Effect of Improving Water Quality at the El-Rahawy and the Tala Drains in the Rosetta Branch Water Quality
}

\author{
Mohamed K. Mostafa \\ Department of Civil, Construction, and Environmental Engineering, University of Alabama at Birmingham, \\ Birmingham, USA \\ Email:mkhaled@uab.edu
}

Received 19 September 2015; accepted 3 November 2015; published 6 November 2015

Copyright (C) 2015 by author and Scientific Research Publishing Inc.

This work is licensed under the Creative Commons Attribution International License (CC BY).

http://creativecommons.org/licenses/by/4.0/

(c) (i) Open Access

\section{Abstract}

The El-Rahawy and the Tala drains are the major sources of pollution along the Rosetta branch. The El-Rahawy drain receives primary treated wastewater from the Abu-Rawash Wastewater Treatment Plant (WWTP), while the Tala drain receives discharge from dairy industry and agricultural drainage, as well as domestic wastewater. This research involved attempting to study the effect of improving water quality on the El-Rahawy and the Tala drains in the Rosetta branch water quality. Water quality at the El-Rahawy drain is expected to improve after discharging water from the Al-Buhairi Water Canal to the El-Rahawy drain and improving effluent water quality at the Abu-Rawash WWTP. Water quality at the Tala drain is expected to improve after constructing a new WWTP and improving effluent water quality at the dairy industry. The river pollutant (RP) modeling enabled studying the effect of improving water quality at the drains on the Rosetta branch water quality. The RP modeling showed that applying the proposed solutions would significantly improve water quality at the Rosetta branch.

\section{Keywords}

El-Rahawy Drain, Tala Drain, Aluminum Chloride, Carbon Dioxide, RP Modeling, Rosetta Branch

\section{Introduction}

Agricultural drains form major sources of pollution along the Rosetta branch. The five agriculture drains located along the path of the Rosetta branch include the El-Rahawy, the Sabal, the El-Tahrer, the Zawyet El-Bahr, and 
the Tala. The effect of the El-Tahrir drain on the water quality is not significant because this drain does not receive domestic or industrial wastes [1]. The Zawyet El-Baher drain also has a minor effect as a result of the low flow rates from this drain. The Sabal drain is polluted mainly by domestic and agriculture wastewater, but has a minor effect as a result of the low flow rate [1]. The El-Rahawy and the Tala drainsare the major source of pollution along the Rosetta branch [1]. The El-Rahawy drain receives approximately 1.90 million $\mathrm{m}^{3}$ (501,926,900 gallons) of drainage water daily from the Zenen and the Abu-Rawash wastewater treatment plants (WWTPs), as well as from agricultural drainage [2] [3]. The effluent from the Zenen WWTP agrees with the limits specified in Egyptian law 48/1982, but the effluent from the Abu-Rawash WWTP does not meet the legal requirements. The main problem is that the Abu-Rawash WWTP provides only a primary treatment and receives flow above its design capacity [4] [5]. Therefore, the Abu-Rawash WWTP represents the main cause of water quality degradation at the El-Rahawy drain and the Rosetta branch [6]. The drains' water quality standards specified in Egyptian law 48/1982 for chlorides $\left(\mathrm{Cl}^{-}\right)$, total dissolved solids (TDS), biological oxygen demand (BOD), dissolved oxygen (DO), total organic carbon (TOC), total suspended solids (TSS), and chemical oxygen demand (COD) are $\leq 500 \mathrm{mg} / \mathrm{L}, \leq 650 \mathrm{mg} / \mathrm{L}, \leq 60 \mathrm{mg} / \mathrm{L}, \geq 4 \mathrm{mg} / \mathrm{L}, \leq 3 \mathrm{mg} / \mathrm{L}, \leq 50 \mathrm{mg} / \mathrm{L}$, and $\leq 80 \mathrm{mg} / \mathrm{L}$, respectively [1]. The average concentrations of $\mathrm{Cl}^{-}$, TDS, BOD, DO, TOC, TSS, and COD in the El-Rahawy drain were 250.20, $720,146.70,1.45,9.2,159.25$, and $270 \mathrm{mg} / \mathrm{L}$, respectively [7]. Consequently, the water quality at the El-Rahawy drain does not meet the legal requirements specified in Egyptian law 48/1982.

Several studies have been conducted to address the effect of the El-Rahawy drain in the Rosetta branch water quality. Abdo [8] observed high levels of contaminants at the discharge point of the El-Rahawy drain and concluded that the El-Rahawy drain was the major source of pollution along the Rosetta branch. Elewa et al. [3] collected water samples from different points along the El-Rahawy drain and the Rosetta branch; the authors observed high levels of TSS, TDS, COD, and BOD in the El-Rahawy drain and in the Rosetta branch downstream the El-Rahawy drain. Moustafa et al. [9] collected water samples from different points along the Rosetta branch. The authors observed high concentrations of bicarbonate $\left(\mathrm{HCO}_{3}\right)$, TDS, $\mathrm{COD}$, and BOD, as well as low levels of DO, at the discharge point of El-Rahawy drain. Other studies of water quality at the Rosetta branch included were conducted by Ezzat et al. [10], who collected water samples from the Rosetta branch and from the point sources located along its path. The analysis of the water samples showed that the water quality at the Rosetta branch was adversely affected by receiving discharge from the El-Rahawy drain, where high concentrations of TDS, $\mathrm{DO}$, turbidity, $\mathrm{BOD}$, ammonia $\left(\mathrm{NH}_{3}\right)$, and total alkalinity were recorded at the discharge point of El-Rahawy drain [10]. Mostafa [1] conducted a study to assess and manage water quality of the Rosetta branch. The author collected water samples from point sources located along the Rosetta branch and from different points along the branch for analysis; results of the analysis revealed high concentrations of $\mathrm{Cl}^{-}, \mathrm{BOD}, \mathrm{COD}$, TSS, and TDS, at the discharge points of the El-Rahawy and the Tala drains.

The Tala drain is the second main pollution source along the Rosetta branch; it receives industrial wastewater from dairy industry, agricultural drainage, and domestic wastewater from homes that do not have access to the sewer networks. The dairy industry discharges about $1,452,946$ gallons $\left(5500 \mathrm{~m}^{3}\right)$ of wastewater every year. Four villages discharge about 52,834,410 gallons $\left(200,000 \mathrm{~m}^{3}\right)$ of domestic wastewater daily to the Tala drain without prior treatment. The average concentrations of $\mathrm{Cl}^{-}$, TDS, BOD, DO, TOC, TSS, and COD in the Tala were $265,896.40,89.60,2.23,10,94.87$, and $181.77 \mathrm{mg} / \mathrm{L}$, respectively [7]. Consequently, the water quality at the Tala drain does not meet the legal requirements specified in Egyptian law 48/1982.

\section{Materials and Methods}

The river pollutant (RP) modeling was used to study the effect of improving water quality at the El-Rahawy and Tala drains on the Rosetta branch water quality [1]. The RP modeling is a river water quality model used to calculate water quality parameters such as $\mathrm{pH}, \mathrm{COD}, \mathrm{BOD}, \mathrm{TDS}, \mathrm{TOC}, \mathrm{Cl}^{-}, \mathrm{DO}$, and temperature [1]. The RP modeling uses the exponential and the mass balance equations to mathematically estimate the values of these parameters along the study area. Data required to run the RP modeling include the flow rateupstream of the first point source and from point sources located along the study area, the parameters concentration from point sources and upstream from the first point source, and the water velocity downstream from each point source. The flow rate was calculated by multiplying the cross-sectional area by the flow velocity. A weighted wire enabled measurement of the depth at a number of points across the width of the river and the point sources. The 
ruler tool in Google Earth enabled measurement of the surface width of the river and the point sources. A water flow probe allowed measurement of the flow velocity.

The five point sources located along the path of the Rosetta branch include the El-Rahawy drain, the Sabal drain, the El-Tahrer drain, the Zawyet El-Bahr drain, and the Tala drain. Figure 1 shows the sampling points along the study area. The water samples were then analyzed for TOC, TDS, TSS, BOD, COD, pH, DO, and $\mathrm{Cl}^{-}$ according to the standard methods for water analysis [11]. Standard quality control and assurance procedures were used for the analysis of the samples [11]. The DO, TDS, and pH were measured in the field, while the other parameters were measured in the laboratory. The test method 2540D and the ion chromatography method $4110 \mathrm{~B}$ were used in the determination of the TSS and chlorides $\left(\mathrm{Cl}^{-}\right)$concentrations in the water samples, respectively. The closed reflux method 5220C and 5-day BOD test 5210B enabled determination of the COD and BOD concentration in the samples, respectively. A Shimadzu TOC-4200 analyzer and the HM digital TDS meter allowed measurement of TOC and TDS concentrations, respectively. The WTW multi 340i meter enabled measurement of $\mathrm{pH}$ and $\mathrm{DO}$ levels in the samples.

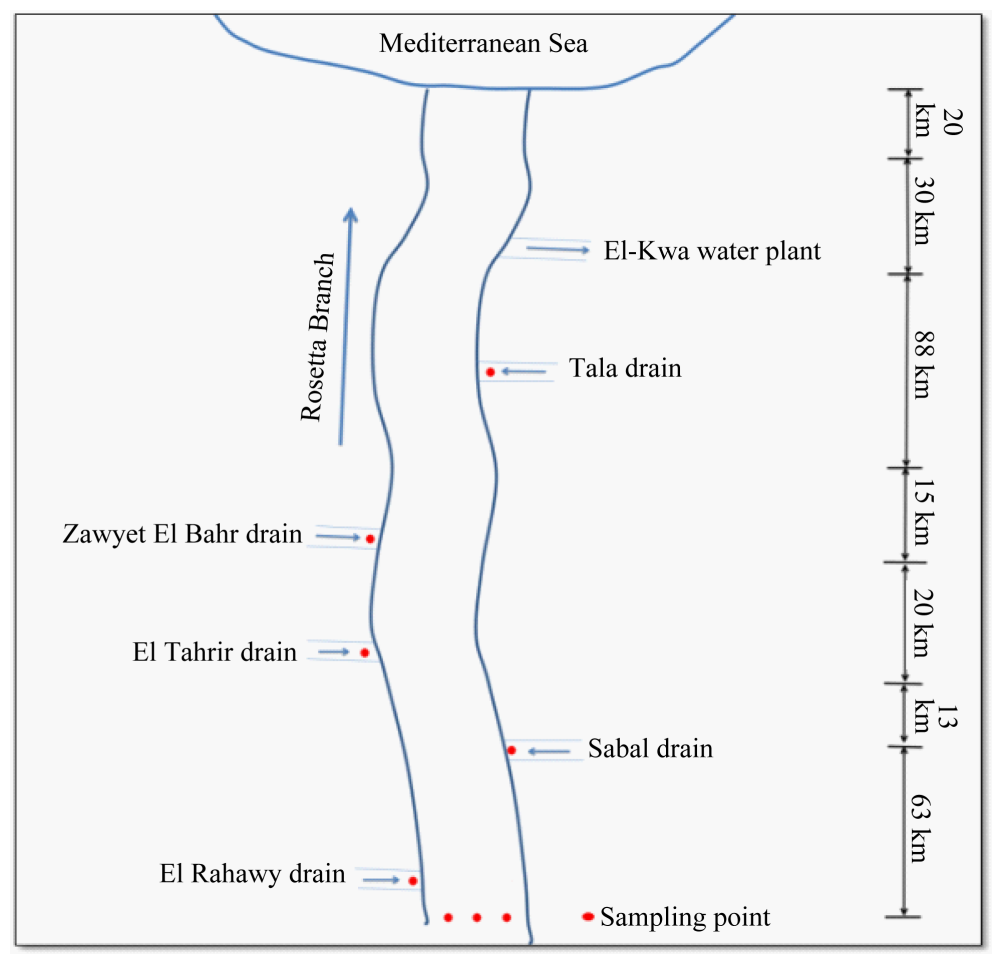

Figure 1. Schematic diagram for water-sampling locations along the Rosetta branch.

\section{Results and Discussion}

\subsection{The El-Rahawy and the Tala Drains}

Mostafa (2014) and Mostafa (2015) conducted a study to assess and manage water quality at the El-Rahawy drain [1] [7]. The author investigated the effectiveness of aluminum chloride $\left(\mathrm{AlCl}_{3}\right)$ along with carbon dioxide $\left(\mathrm{CO}_{2}\right)$ in wastewater treatment. The author also investigated the effectiveness of discharging 264,172,000 gallons $\left(1.0\right.$ million $\left.\mathrm{m}^{3}\right)$ of water from a canal that flows perpendicular to the El-Rahawy drain. The author concluded that applying these solutions will significantly improve water quality at the El-Rahawy drain. Water flow and characterization at the El-Rahawy drain for the current and proposed solution, are presented in Table 1.

Mostafa (2015) conducted a study to assess and manage water quality at the Tala drain [12]. The author investigated the effectiveness of using $\mathrm{AlCl}_{3}$ along with $\mathrm{CO}_{2}$ in dairy wastewater treatment. The author also investigated the effectiveness of constructing a new WWTP on the Tala drain water quality. The author concluded that 
Table 1. Water flow and characterization at the El-Rahawy drain.

\begin{tabular}{ccc}
\hline Term & Current situation & Proposed solution \\
Flow, $\mathrm{m}^{3} / \mathrm{day}$ & $1,900,000$ & (First approach + second approach) \\
BOD, $\mathrm{mg} / \mathrm{L}$ & 140 & $2,900,000$ \\
$\mathrm{COD}, \mathrm{mg} / \mathrm{L}$ & 270 & 34.48 \\
TOC, $\mathrm{mg} / \mathrm{L}$ & 12 & 65.60 \\
TDS, $\mathrm{mg} / \mathrm{L}$ & 820 & 1.50 \\
TSS, $\mathrm{mg} / \mathrm{L}$ & 150 & 296.60 \\
DO, $\mathrm{mg} / \mathrm{L}$ & 1.45 & 32.25 \\
$\mathrm{pH}$, dimensionless & 7.40 & 3.22 \\
\hline
\end{tabular}

First approach: improve water quality at the Abu-Rawash WWTP by using $\mathrm{AlCl}_{3}$ and $\mathrm{CO}_{2}$; Second approach: discharging flow from Al-Buhairi Water Canal to the El-Rahawy drain.

applying these solutions will significantly improve water quality at the Tala drain. Water flow and characterization at the Tala drain for the current and proposed solution, are presented in Table 2.

Table 2. Water flow and characterization at the Tala drain [12].

\begin{tabular}{ccc}
\hline Term & Current situation & Proposed solution \\
\cline { 2 - 2 } Flow, $\mathrm{m}^{3} / \mathrm{day}$ & & (First approach + second approach) \\
BOD, $\mathrm{mg} / \mathrm{L}$ & 449,878 & 449,878 \\
COD, $\mathrm{mg} / \mathrm{L}$ & 89.60 & 24.80 \\
TOC, $\mathrm{mg} / \mathrm{L}$ & 181.77 & 48.34 \\
TDS, $\mathrm{mg} / \mathrm{L}$ & 10.0 & 5.10 \\
TSS, $\mathrm{mg} / \mathrm{L}$ & 896.4 & 629.70 \\
DO, $\mathrm{mg} / \mathrm{L}$ & 94.87 & 30.20 \\
$\mathrm{pH}$, dimensionless & 2.23 & 2.42 \\
\hline
\end{tabular}

First approach: improve water quality at the dairy industry by using $\mathrm{AlCl}_{3}$ and $\mathrm{CO}_{2}$; Second approach: constructing a new WWTP.

\subsection{RP Modeling Results}

The river pollutant (RP) modeling was used to predict improvement in the Rosetta branch water quality after water quality was improved at the El-Rahawy and the Tala drains. The water quality was improved at the ElRahawy drain by discharging clean water to the El-Rahawy drain and by improving effluent water quality at the Abu-Rawash WWTP. The water quality was improved at the Tala drain by constructing a new WWTP and improving effluent water quality from the dairy industry [1]. The average values of the physical-chemical analysis for water samples collected upstream the El-Rahawy drain and from the point sources located along the study area are presented in Table 3. This data is required to run the RP modeling. 
Table 3. The analysis of water samples collected from pollution sources located along the Rosetta branch [1].

\begin{tabular}{ccccccccc}
\hline Location/parameter & Avg pH & $\begin{array}{c}\text { Avg TDS, } \\
\mathrm{mg} / \mathrm{L}\end{array}$ & $\begin{array}{c}\mathrm{Avg} \\
\mathrm{DO}, \mathrm{mg} / \mathrm{L}\end{array}$ & $\begin{array}{c}\mathrm{Avg} \mathrm{Cl} \\
\mathrm{mg} / \mathrm{L}\end{array}$ & $\begin{array}{c}\text { Avg BOD, } \\
\mathrm{mg} / \mathrm{L}\end{array}$ & $\begin{array}{c}\mathrm{Avg} \mathrm{COD}, \\
\mathrm{mg} / \mathrm{L}\end{array}$ & $\begin{array}{c}\text { Avg TOC, } \\
\mathrm{mg} / \mathrm{L}\end{array}$ & $\begin{array}{c}\text { Avg TSS, } \\
\mathrm{mg} / \mathrm{L}\end{array}$ \\
\hline Upstream El-Rahawy drain & 8.30 & 230.0 & 6.0 & 71.0 & 5.0 & 10.0 & 0.6 & 50.0 \\
El-Rahawy drain & 7.40 & 820.0 & 1.45 & 271.0 & 140.0 & 270.0 & 12.0 & 150.0 \\
Sabal drain & 7.90 & 680.0 & 2.50 & 265.0 & 60.0 & 122.0 & 9.30 & 190.0 \\
El-Tahrir drain & 8.50 & 450.0 & 3.50 & 116.0 & 20.0 & 41.0 & 2.25 & 124.0 \\
Zawyet El-Bahr drain & 7.9 & 600 & 2.5 & 81 & 50 & 103 & 2.8 & 80 \\
Tala drain & 7.8 & 896.40 & 2.23 & 265 & 89.60 & 181.77 & 10 & 94.87 \\
\hline
\end{tabular}

The simulations of the current situation and the proposed solution are shown in Figures 2-9. The water quality standard specified in Egyptian law 48/1982 and EPA standards for BOD is $6.0 \mathrm{mg} / \mathrm{L}$ [13] [14]. In the current situation, the BOD concentrations downstream of the El-Rahawy and the Tala drains were about 15.95 and $14.02 \mathrm{mg} / \mathrm{L}$, respectively. These values clearly exceeded the water quality standards, as shown in Figure 2 . After water quality at the El-Rahawy and the Tala drains is improved, the BOD concentrations downstream of the El-Rahawy and the Tala drains will decrease to 8.4 and $7.7 \mathrm{mg} / \mathrm{L}$, respectively. In comparison with findings for the current situation, those resulting from applying the proposed solution will reduce the BOD concentration downstream of the El-Rahawy and the Tala drains by about 46.8\%.Consequently, if the proposed solution is applied, the BOD concentration downstream of the El-Rahawy drain will become very close to acceptable levels, which leads to improving the water quality at the Rosetta branch. The chlorides concentration downstream of the El-Rahawy and the Tala drains did not exceed the $250 \mathrm{mg} / \mathrm{L}$ maximum value specified in Egyptian law 48/1982 and EPA standards [13] [14]. After water quality at the El-Rahawy and the Tala drains is improved, the chlorides concentration along the study area will decrease by about $15.3 \%$ (see Figure 3 ).

The water quality standard specified in Egyptian law 48/1982 and EPA standards for COD is 10.0 mg/L [13] [14]. For the current situation, the COD concentrations downstream of the El-Rahawy and the Tala drains were about 31.09 and $27.6 \mathrm{mg} / \mathrm{L}$, respectively. These values clearly exceeded the water quality standards, as shown in Figure 4. After water quality at the El-Rahawy and the Tala drains is improved, the COD concentrations downstream of the El-Rahawy and the Tala drains will decrease to 16.58 and $15.18 \mathrm{mg} / \mathrm{L}$, respectively. In comparison with findings for the current situation, those resulting from applying the proposed solution will reduce the COD concentration downstream of the El-Rahawy and the Tala drains by about $47.0 \%$. Applying the proposed solution will significantly decrease the negative effect of the El-Rahawy and the Tala drains in the Rosetta branch water quality because the COD concentration downstream of the El-Rahawy drain will become very close to acceptable levels after improving water quality at this drain. The water quality standard specified in Egyptian

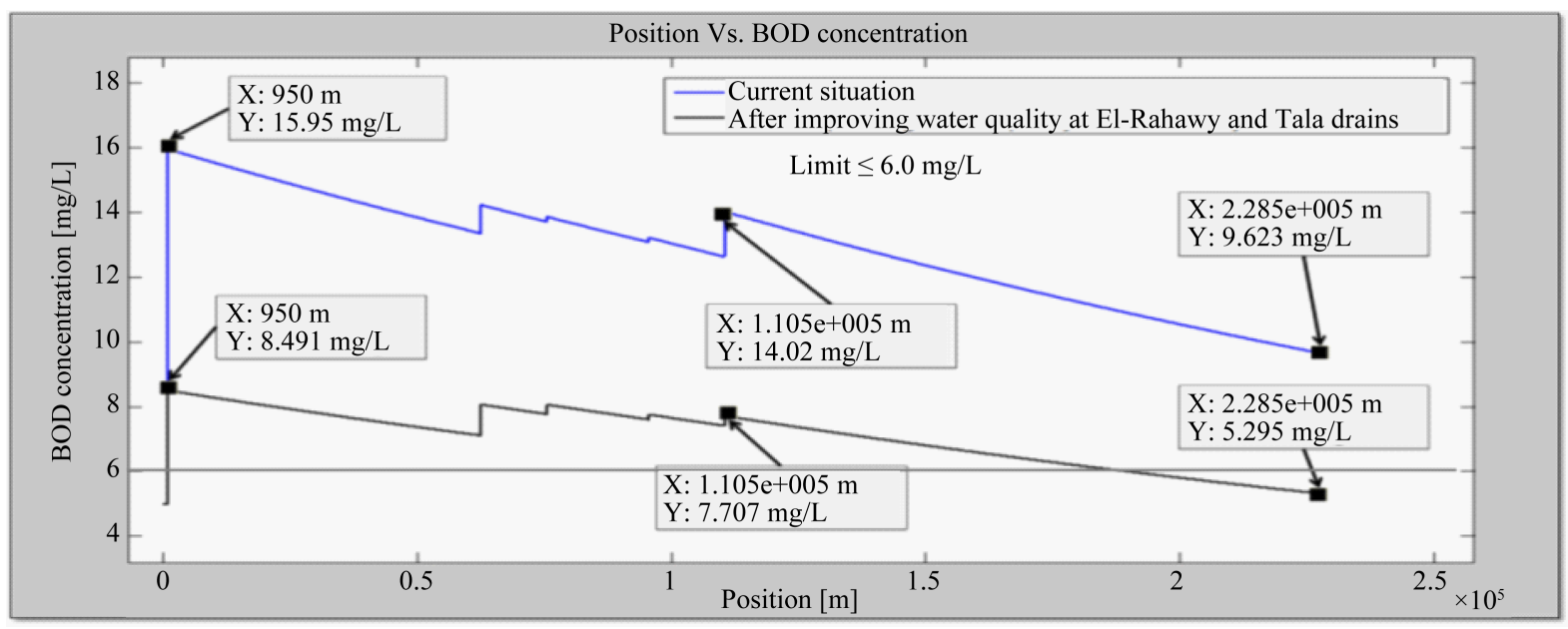

Figure 2. BOD concentration along the Rosetta branch for current situation and proposed solution. 


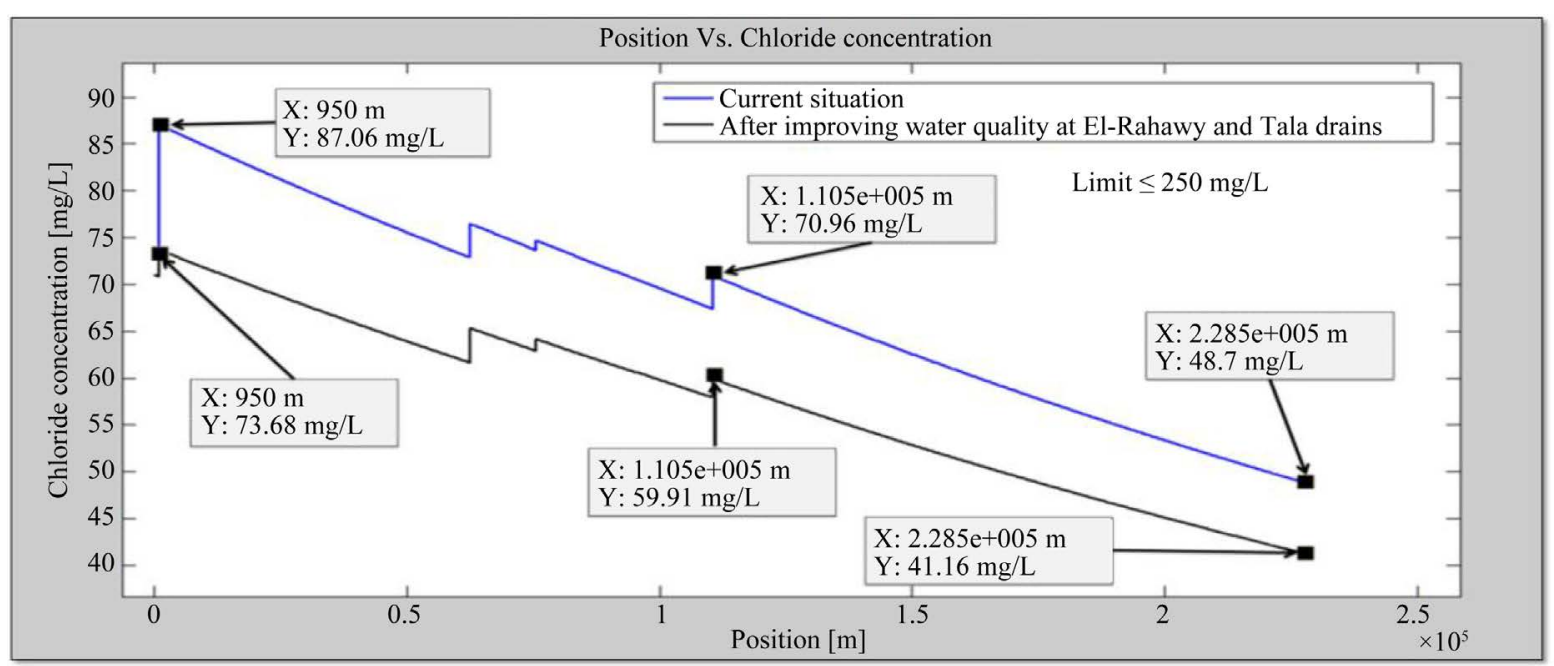

Figure 3. Chlorides concentration along the Rosetta branch for current situation and proposed solution.

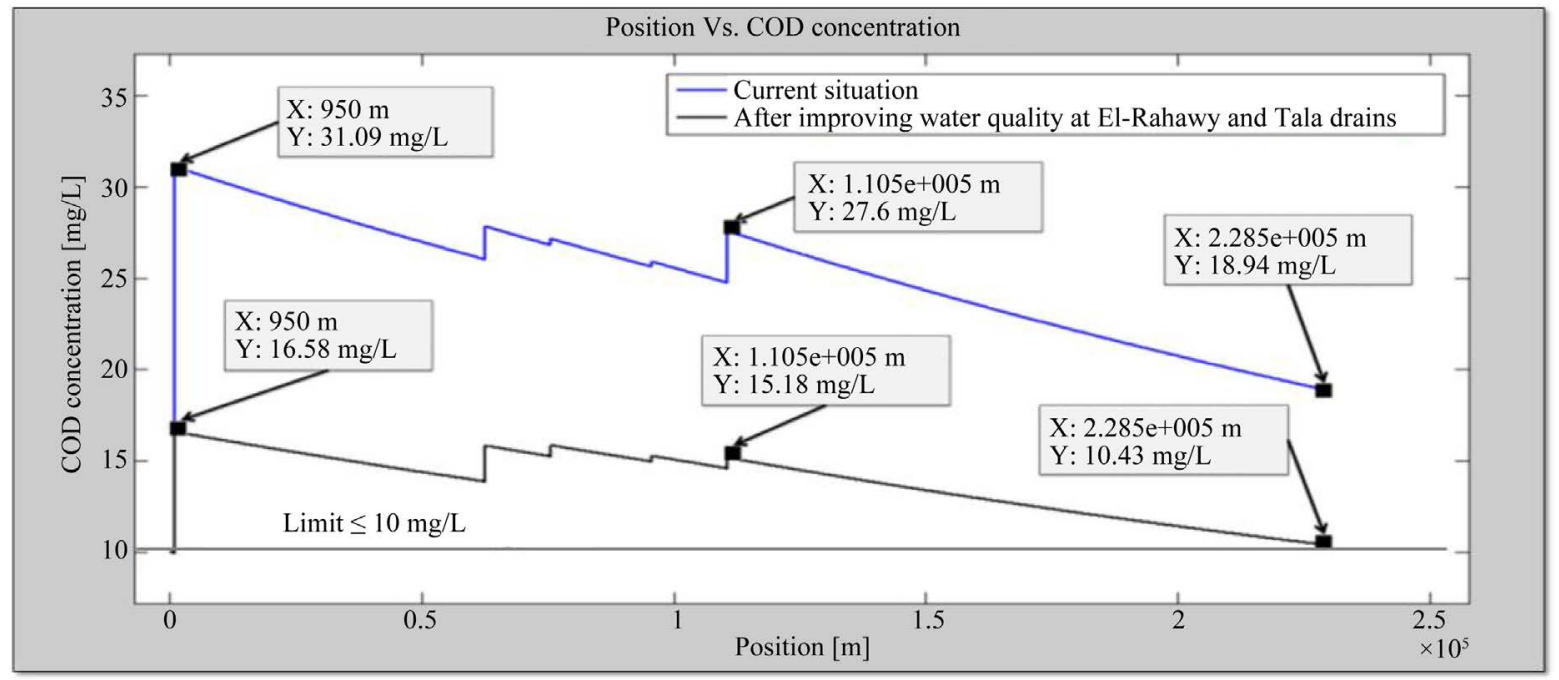

Figure 4. COD concentration along the Rosetta branch for current situation and proposed solution.

law 48/1982 and EPA standards for TDS is $\leq 500 \mathrm{mg} / \mathrm{L}$ [13] [14]. For the current situation, the TDS concentration along the branch did not exceed the $500 \mathrm{mg} / \mathrm{L}$ maximum value specified in Egyptian and EPA standards; thus, the TDS concentration in the Rosetta branch is not negatively affected by receiving discharge from the ElRahawy and the Tala drains (see Figure 5). After water quality at the El-Rahawy and the Tala drains is improved, the TDS concentration along the study area will decrease by about $14.4 \%$.

The $\mathrm{pH}$ value specified in Egyptian law 48/1982 and EPA standards ranges from 7.0 to 8.5 [13] [14]. The pH value upstream of the El-Rahawy drain was about 8.3, which agrees with water quality standards (see Figure 6). The $\mathrm{pH}$ value downstream of the El-Rahawy drain is expected to decrease from 8.10 to 7.3 because of the use of carbon dioxide in wastewater treatment at the Abu-Rawash WWTP. For the current situation and the proposed solution, the $\mathrm{pH}$ value along the Rosetta branch is in agreement with the water quality standards specified in Egyptian and EPA standards. Consequently, the $\mathrm{pH}$ value in the Rosetta branch is not negatively affected by using carbon dioxide in wastewater treatment. The DO concentration specified in Egyptian law 48/1982 and EPA standards is $\geq 4.0 \mathrm{mg} / \mathrm{L} \mathrm{[13]} \mathrm{[14].} \mathrm{In} \mathrm{the} \mathrm{two} \mathrm{cases,} \mathrm{the} \mathrm{DO} \mathrm{concentration} \mathrm{along} \mathrm{the} \mathrm{Rosetta} \mathrm{branch} \mathrm{was} \mathrm{within}$ the standard limits in all areas but downstream of the Tala drain (see Figure 7). In comparison with findings for the current situation, those resulting from applying the proposed solution will slightly increase DO concentration along the Rosetta branch. 


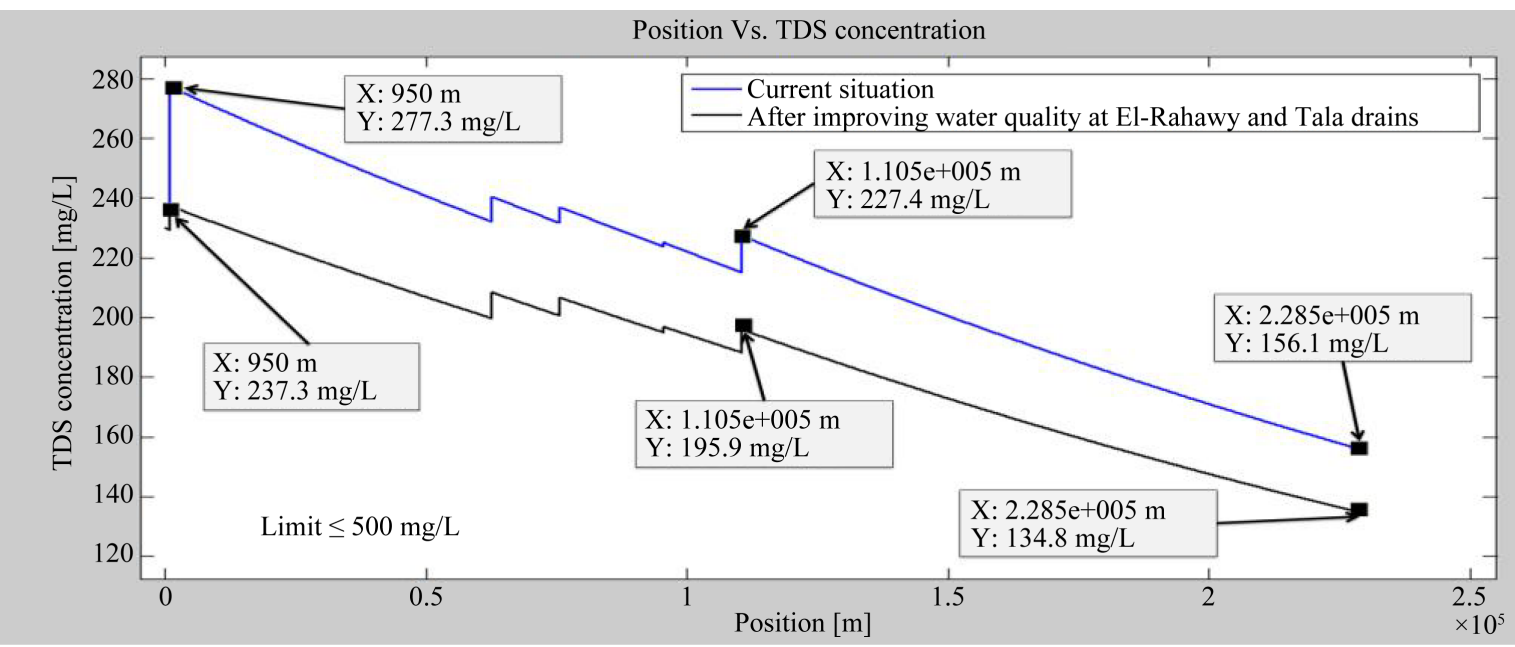

Figure 5. TDS concentration along the Rosetta branch for current situation and proposed solution.

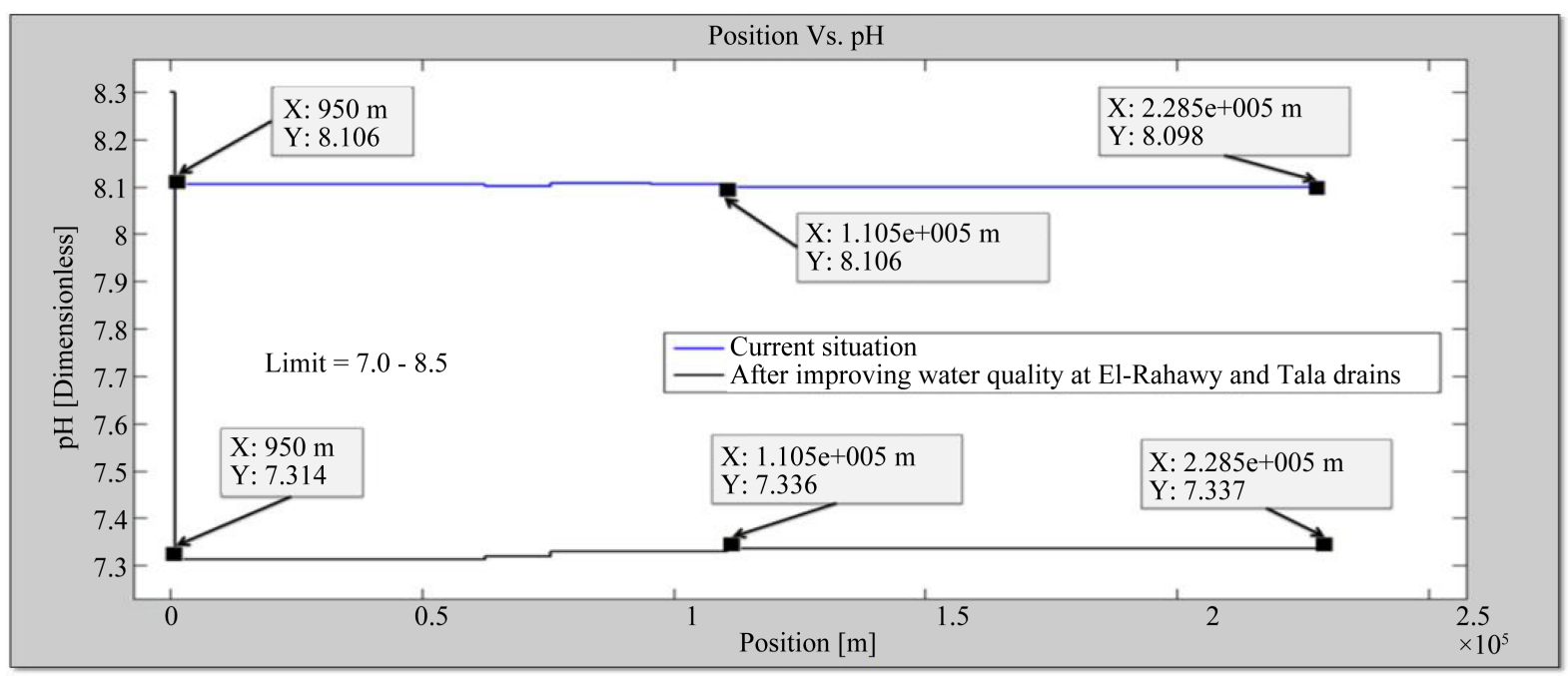

Figure 6. $\mathrm{pH}$ value along the Rosetta branch for current situation and proposed solution.

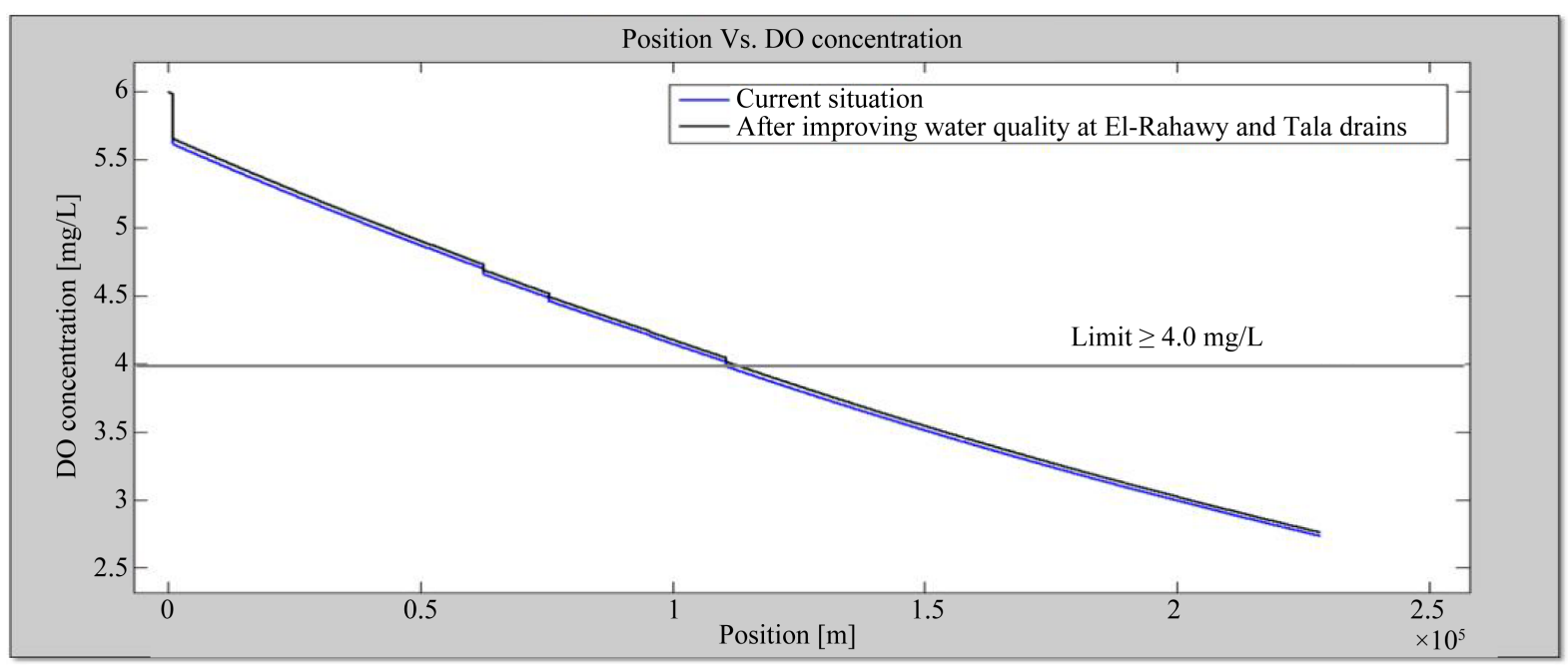

Figure 7. DO concentration along the Rosetta branch for current situation and proposed solution. 
The TOC concentration upstream of the El-Rahawy drain was approximately $0.6 \mathrm{mg} / \mathrm{L}$, which clearly is within the $3.0 \mathrm{mg} / \mathrm{L}$ maximum value specified in Egyptian law 48/1982 [13]. In the two cases, the TOC concentration along the study area was also within the permissible limits. After water quality at the El-Rahawy and the Tala drains is improved, the TOC concentration will decrease by about $62 \%$ downstream the El-Rahawy drain and by about $36 \%$ downstream the Tala drain (see Figure 8). The TSS concentration upstream of the El-Rahawy drain was about $50 \mathrm{mg} / \mathrm{L}$, which clearly exceeded the $20 \mathrm{mg} / \mathrm{L}$ maximum value specified in Egyptian law 48/ 1982 and EPA standards [13] [14]. After water quality at the El-Rahawy and the Tala drains is improved, the TSS concentrations downstream of the El-Rahawy and the Tala drains are expected to decrease from 58.0 to $47.77 \mathrm{mg} / \mathrm{L}$ and from 47.02 to $38.81 \mathrm{mg} / \mathrm{L}$, respectively (see Figure 9). Consequently, the TSS concentration in the Rosetta branch is negatively affected by receiving discharge from the El-Rahawy and the Tala drains.

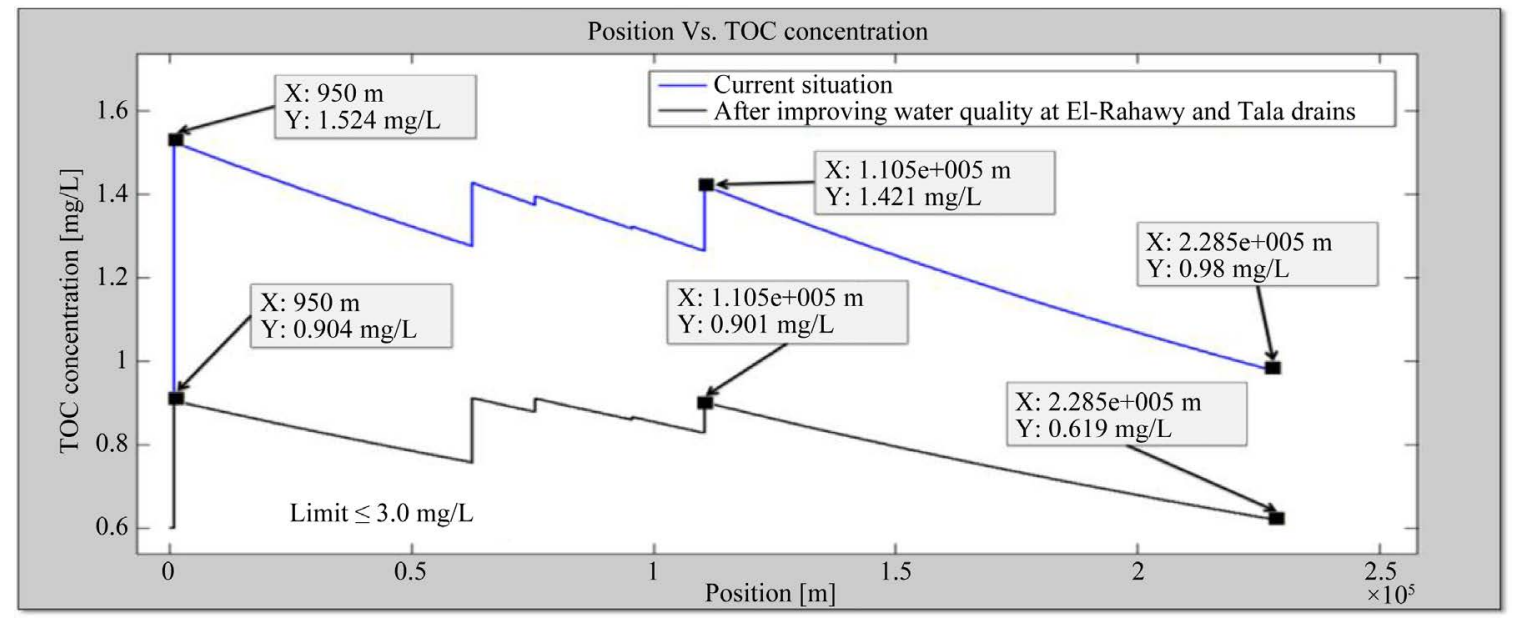

Figure 8. TOC concentration along the Rosetta branch for current situation and proposed solution.

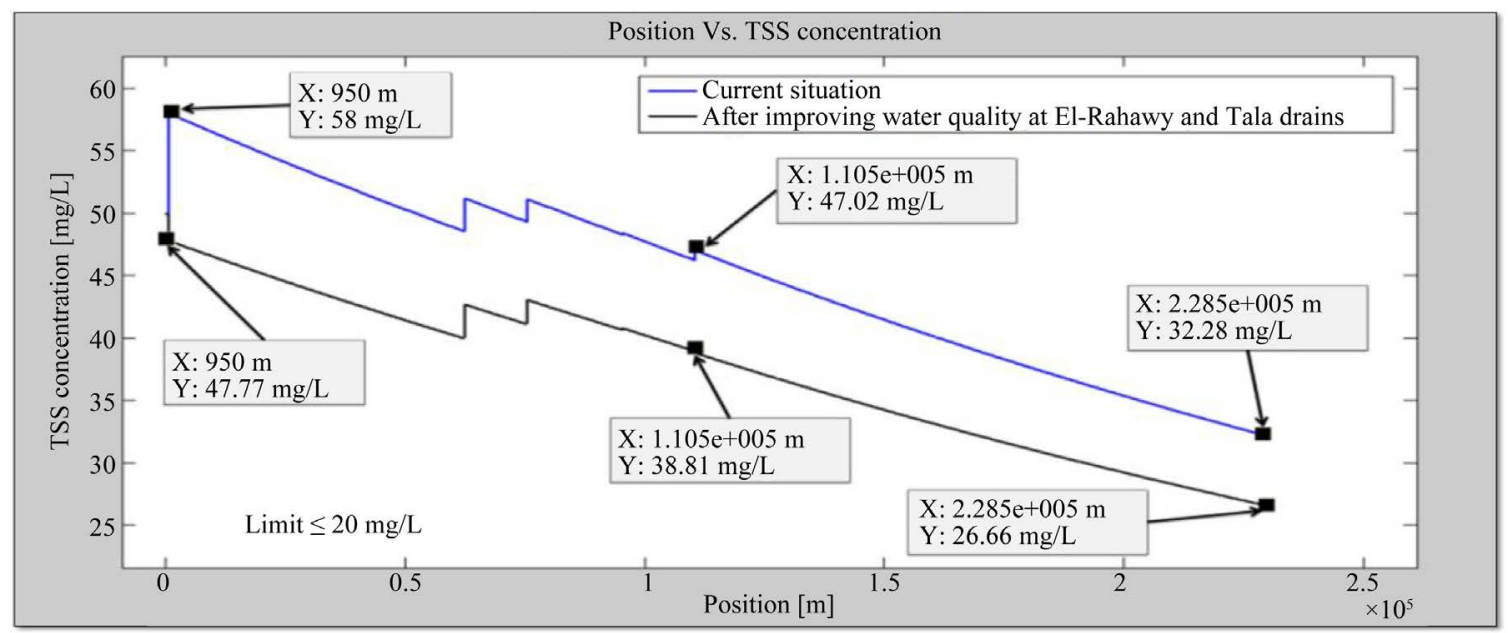

Figure 9. TSS concentration along the Rosetta branch for current situation and proposed solution.

\section{Conclusion}

Results showed that improving effluent water quality at the Abu-Rawash WWTP and discharging water from the Al-Buhairi Water Canal to the El-Rahawy drain would significantly improve the water quality at the El-Rahawy drain. Results also showed that improving effluent water quality at the dairy industry and constructing a new WWTP would significantly improve the water quality at the Tala drain. The RP modeling showed that the concentrations of COD, TDS, BOD, TSS, TOC, and chlorides along the Rosetta branch were expected to decrease significantly after improving water quality at the El-Rahawy and the Tala drains. In addition, a slight in- 
crease in dissolved oxygen concentration is expected to occur. The RP modeling also showed that the pH value along the Rosetta branch was expected to decrease due to using carbon dioxide in wastewater treatment, but it was still in agreement with the water quality standards specified in Egyptian and EPA standards.

\section{Acknowledgements}

This research was supported by the Department of Civil, Construction, and Environmental Engineering at the University of Alabama at Birmingham. The authors also thank the Egyptian Housing Building Research Center for their help in collecting samples and performing the chemical analyses.

\section{References}

[1] Mostafa, M. (2014) Modeling of Pollutant Transport in the Nile Delta Egypt. PhD Dissertation, Department of Civil, Construction, and Environmental Engineering, University of Alabama at Birmingham, Birmingham.

[2] Elewa, A.A., Shehata, M.B., Mohamed, L.F., Badr, M.H. and Abdel-Aziz, G.S. (2009) Water Quality Characteristics of the River Nile at Delta Barrage with Special Reference to Rosetta Branch. Global Journal of Environ. Research, 3, $1-6$.

[3] Gaber, H.S., Midhat, A.E., Seham, A.I. and Mohammad, M.N.A. (2013) Effect of Water Pollution in El-Rahawy Drainage Canal on Hematology and Organs of Freshwater Fish Clariasgariepinus. World Applied Sciences Journal, 21, 329-341.

[4] El-Bouraie, M.M., Eman, A.M., Gehad, G.M., Essam, H.A. and Mohamed, M.Y. (2011) Water Quality of Rosetta Branch in Nile Delta, Egypt. Suoseura, 62, 31-37.

[5] Ministry of Housing, Utilities and Urban Development (2010) Availability and Operation of Abu-Rawash Wastewater Treatment Plant: Amended Information Memorandum.

[6] Misheloff, R. (2010) Integrated Water Resource Management II: Feasibility of Wastewater Reuse, International Resources Group. Report No. 14, United States Agency for International Development (USAID), Washington DC.

[7] Mostafa, M.K. (2015) Improve Effluent Water Quality at Abu-Rawash WWTP Using Aluminum Chloride and Carbon Dioxide. Journal of Water Resource and Protection, 7, 1049-1057. http://dx.doi.org/10.4236/jwarp.2015.713086

[8] Abdo, M.H. (2002) Environmental Studies on Rosetta Branch and Some Chemical Applications at the Area Extend from El-Kanater El-Khyria to Kafr-El-Zyat City. PhD Thesis, Faculty of Science, Ain Shams University, Cairo.

[9] Moustafa, M.M., Mohamed, H.H.A., Amal, M.A., Talat, M. and Siliem, M.M. (2010) Water Quality Assessment of Rosetta and Damietta Branches, River Nile, Egypt. African Journal of Biological Sciences, 6, 127-142.

[10] Ezzat, S.M., Hesham, M.M., Mervat, A.A., Essam, H.A. and Mostafa, A.E. (2012) Water Quality Assessment of River Nile at Rosetta Branch: Impact of Drains Discharge. Middle-East Journal of Scientific Research, 12, 413-423.

[11] Andrew, D.E., Lenore, S.C., Eugene, W.R. and Arnold, E.G. (2005) Standard Methods for the Examination of Water and Wastewater. 21st Edition, American Public Health Association, Washington DC.

[12] Mostafa, M.K. (2015) Impact of Improving Water Quality at the Tala Drain on the Rosetta Branch Water Quality. Journal of Environmental Protection, 6, 1149-1157. http://dx.doi.org/10.4236/jep.2015.610102

[13] National Water Research Center (NWRC) (1995) River Nile Protection and Development Project Phase II. Environmental Pollution and Legislative Regulations (Law 48. 1982 \& Decree 8, 1993), Ministry of Public Works and Water Resources, Cairo.

[14] Environmental Protection Agency (EPA) (2007) Drinking Water Standards and Health Advisories Table, San Francisco, CA. 